\title{
Turning a Blind Eye: The United States and the Israeli Nuclear Program
}

\author{
Arie Geronik
}

The aim of this paper is to examine the reasoning behind the ongoing U.S. policy of, in effect, ignoring Israel's nuclear capability. By law, the American administration is obligated to impose sanctions on every country that joins the "Nuclear Club." Despite this, not only has the United States not imposed sanctions on Israel, but the latter enjoys the lion's share of U.S. foreign aid. This article tries to follow the logic of this policy. My hypothesis is that by ignoring Israel's nuclear policy (of ambiguity), the United States can continue to declare her ongoing commitment to the security of Israel, while not having to anchor it in a formal pact. By adopting such a policy, both sides can "have their cake and eat it too."

Keywords nuclear proliferation, nuclear policy, U.S.-Israel relations, national interests, security policy

\section{Introduction}

Of all the aspects of Israel's national security policy, not one has as the degree of massive public support in Israel as does the policy of "nuclear ambiguity." According to this policy, Israel officially makes no comment regarding its nuclear status, activities, or capabilities. It neither confirms nor denies anything.

Israel's policy of nuclear ambiguity relies on an unwritten understanding between Prime Minister Golda Meir and President Richard Nixon arrived at in 1969, by which Israel would maintain a certain vagueness regarding the nuclear issue and would not conduct nuclear tests. In return, the United States would avoid pressuring Israel into joining the Treaty on the Non-Proliferation of Nuclear Weapons (NPT). Following their meeting, the two leaders documented what was said. However, the original documentation of the conversation exists in neither the American nor the Israeli National Archives. Moreover, according to Avner Cohen (2009), "American documents recently declassified indicate that about a month after that conversation, even Henry Kissinger, at the time Nixon's 
national security adviser, was not fully aware of the exact details of what the two agreed on."

The surprising absence of documentation indicates the high sensitivity of the issue; it seems that as a result, researchers' access to the past is limited and we are doomed to ambiguity, both concerning the content of the conversation and the motives for the understandings reached. "In Israel's political folklore, the Nixon-Meir understandings are considered an unparalleled success story. They have always been interpreted as an American commitment to shield Israel's nuclear program, while it remains committed to restraint and opacity. These understandings indeed shielded Israel but put it in the position of a "nuclear mistress," the kind you cannot be seen with in public" (ibid.).

\section{The U.S. Position toward Israel's Nuclear Policy (1958-1970) ${ }^{1}$}

The United States first became aware of the Dimona installation in 1958, but only toward the end of 1960 did Israel's Prime Minister Ben Gurion admit to its being a nuclear installation (though, according to him, for peaceful purposes only). The Prime Minister's announcement in the Knesset came between the 1960 presidential elections and John F. Kennedy's inauguration. Just one month after becoming president, Kennedy demanded that Ben Gurion allow American inspectors to visit the site. Ben Gurion responded with a generalization, saying that such a visit would be possible, sometime in the future.

Both parties agreed to quiet diplomacy, which enabled the administration to continue talks with Israel on what it considered a sensitive and essential issue, without exposing the administration's weakness during the transition period between the Eisenhower and the Kennedy administrations. In addition, anticipating the reaction of the Arab world, the American administration had an interest in keeping a low profile. Early in January 1961, the American ambassador to Israel, Ogden Reid, met with Prime Minister Ben Gurion and Golda Meir, the Minister of Foreign Affairs, and presented the U.S. demand to receive unequivocal answers to some of the Dimona Project questions. This was probably intended to get a formal written document that would greatly minimize Israel's ambiguity in presenting its position. As Zaki Shalom $(2005,18-19)$ points out, "the surprise exposure of the reactor must have been perceived as an embarrassing failure of the U.S. intelligence services. Little wonder, then, as the full extent of the fiasco became evident that the administration wanted to close the information gap on the Dimona Project as quickly as possible." In addition to that, "there was an ill-concealed feeling of annoyance among officials that the United States has been left in the dark by two of its international friends, France and Israel" (Hersh 1991, 72).

The relative calm of Israeli-American contacts concerning Israel's nuclear 
activity did not reduce Ben Gurion's anxiety about the tough struggle facing Israel regarding the Dimona Project. He had no doubt that some time in the future the American administration would use all means to get as much information as possible about the Dimona Project in order to ensure international or American supervision of it. As a result, a meeting between Ben Gurion and Kennedy was set up and took place on May 30, 1961 in New York.

The meeting was held shortly after a visit to Dimona by two American scientists. The scientists reported that there was no evidence of any military cability being developed there. Moreover, they maintained that their findings were similar to those presented by Israel to the Americans. At their meeting, Kennedy asked Ben Gurion to describe the characteristics and functionality of the Dimona Project. Ben Gurion, who had planned his response, explained the great importance of finding alternative energy sources for Israel, which would solve, among other things, Israel's central problem-the lack of water. The only way to overcome this problem, he asserted, would be desalination of seawater. In order to realize this goal, Israel needed a cheap energy source. That was the reactor's main purpose, according to Ben Gurion. In addition to emphasizing the scientific-research-industrial nature of the Dimona Project, Ben Gurion mentioned Israel's security concerns with the growing power of the Arab world, especially Egypt. He made it clear that he could not promise that in the future Israel would not change the objectives of the Dimona reactor to serve her security needs. Zaki Shalom had the following to offer on the reasoning behind Ben Gurion's statements:

Ben Gurion apparently chose to gamble on this addition in order to buy Israel, and perhaps himself, a crucial insurance policy in the ongoing American-Israeli dialogue. Ben Gurion believed that if the Americans eventually received information that changed their assessment of the peaceful nature of the Dimona Project, then the administration, and President Kennedy in particular, would claim that Israel, and especially Ben Gurion, had consciously deceived them. Such duplicity, Ben Gurion feared, would almost certainly precipitate a serious crisis between the two states at both the political and personal levels (Shalom 2005, 28).

From this point on, the name of the game in all matters concerning the Dimona Project was, from Israel's point of view, buying time. Following the meeting, the two leaders reached an understanding by which Israel would allow two U.S. representatives to visit the Dimona reactor once a year. This actually guaranteed that Israel could avoid unrelenting American pressure on Israel's nuclear activity, at least temporarily. Israel demanded that discussions with the U.S. government concerning the nuclear issue not be held in a public, dramatic, threatening, or embarrassing way, but in a quiet setting.

The understandings between Ben Gurion and Kennedy enabled Israel to preserve and strengthen her deterrence in her relationship with the Arab world. 
It can be assumed that despite the American scientists' report, Arab states had serious doubts about Israel's nuclear activity. The Arab countries could not ignore the possibility that Israel had managed to deceive the United States and was acting secretly to develop a nuclear option. Thus, the Arab world probably assumed that, at some stage, Israel would have a nuclear weapon.

Regarding the factors underlying Kennedy's “indulgent" policy toward the Israeli nuclear project-a policy soon to change-three hypotheses can be raised. First, from a personal point of view, the Ben Gurion-Kennedy meeting took place shortly after the latter took office. He was still a novice in the international diplomatic arena. It is likely that Kennedy was concerned about not getting into a confrontation with a leader such as Ben Gurion, who had begun his public life before Kennedy was born and was a legend in his lifetime. Second, the Kennedy administration formulated its attitude toward the Dimona project shortly after Ben Gurion reported on the capture of Adolf Eichmann on the Knesset floor (on May 23, 1960). Ben Gurion's dramatic announcement and the public trial that ensued in Jerusalem brought the Holocaust to the forefront and served as a reminder of the role of the Western superpowers, which had not acted to foil the extermination of a large part of the Jewish people. These circumstances may have intensified the feeling of obligation of the Americans toward the security of the State of Israel. Members of the administration may have felt uncomfortable in casually depriving Israel of its right to prevent another Holocaust. Third, about a month prior to the meeting with Ben Gurion (in mid-April 1961), the American attempt to collaborate with Cuban exiles to overthrow the Castro government (the Bay of Pigs invasion) failed spectacularly. This failure caused Kennedy great embarrassment. In all likelihood, these issues produced a cumulative effect on the administration's decision to postpone the confrontation with Israel until more convenient circumstances arose.

The low-profile policy continued for a limited time, to be replaced with what can be termed a crushing strategy. The change came about for several reasons. First, with the accumulation of hard-core information, American and British intelligence agencies came to assume that Israel had hidden various aspects regarding its nuclear activity from the U.S. government. Second, according to Cohen $(1998,99)$, "no American president was more convinced that the spread of nuclear weapons would make the world more dangerous and undermine U.S. interests. [Kennedy] saw it as his role to place nuclear arms control and nonproliferation at the center of American foreign policy. In the words of Glenn Seaborg, Kennedy's chairman of the [Atomic Energy Commission], nuclear proliferation was Kennedy's private nightmare."

Another probable factor was the dramatic change in the balance of power between Kennedy and Ben Gurion after their first meeting at the end of May 1961. By the end of 1962, Kennedy's position had significantly strengthened. During the Cuban missile crisis in October 1962, he showed wisdom, self- 
control, decisiveness, and daring. This consolidated the U.S. President's internal and international position. Doubts as to his leadership capabilities disappearedespecially in the international arena-as well as his ability to serve as the leader of the free world. Ben Gurion's position, on the other hand, weakened during that time.

The practical meaning of the new policy was that the Kennedy administration decided to eliminate Israel's nuclear activity in its present format. From the administration's point of view, it was preferable to implement this goal without causing friction with Israel. However, aware that Ben Gurion would oppose it, the administration decided to apply an iron fist policy. Based on sources declassified in recent years, it appears that the pressure exerted on Israel by the administration reached its peak in 1963. In March 1963, on President Kennedy's instructions, National Security Advisor McGeorge Bundy wrote to Secretary of State Rusk, the Chairman of the Atomic Energy Commission, and the Director of Central Intelligence:

The President desires, as a matter of urgency, that we undertake every feasible measure to improve our intelligence on the Israeli nuclear program as well as other Israeli and UAR advanced weapon programs, and to arrive at a firmer evaluation of their import. In this connection he wishes the next informal inspection of the Israeli reactor complex to be undertaken promptly and to be as thorough as possible. In view of his great concern over the destabilizing impact of any Israeli or UAR program looking toward the development of nuclear weapons, the President also wishes the Department of State to develop proposals for forestalling such programs. ${ }^{2}$

During this period, there was also a change in terminology regarding the Dimona Project inspection: though allegedly semantic, the change was in fact fundamental. Instead of a "visit," the term initially used by both the Americans and Israelis since the exposure of the reactor, the new term was "inspection." The administration was well aware of the difference between terms: whereas a "visit" grants the "host," i.e. Israel, the authority to determine the nature of the "visit," its duration as well as the sites where it would take place, an "inspection" transfers most of the authority in this context to the "supervising factor," namely, the United States. This was in clear contrast to the understanding reached by Kennedy and Ben Gurion at their May 1961 meeting.

On May 12, 1963, in reply to a letter he received from Kennedy in early May, Ben Gurion demanded, among other things: full demilitarization of Jordan's West Bank if Hussein should fall, a bilateral security agreement between Israel and the United States, supply of all the equivalent kinds of armament with which the armed forces of Egypt and the other Arab states are equipped, and agreement on a plan of general disarmament in the Middle East.

Ben Gurion's message was clear: if the American administration, knowing of Israel's security concerns, was not willing to sign a defense treaty or supply Israel 
with advanced weaponry, it was only appropriate to let it fend for itself.

On May 19, Kennedy sent Ben Gurion another letter-this one harsh and threatening. The President emphasized at the outset that nothing had higher priority than control over nuclear weapons. On this basis, continued Kennedy, the United States demanded Israel's consent to periodic visits to Dimona by American scientists. Development of nuclear capability by Israel, Kennedy further asserted, would have harsh ramifications on the stability of the world order. Therefore, the considerations referred to in this context were much wider than the narrow aspects regarding the Middle East only. ${ }^{3}$

Kennedy's letter pushed the Israel Government into a corner. It was obvious that the President had decided to "take the gloves off" with his demands for inspection of the Dimona Project. Such a high-ranking application, in unequivocal, scathing language, left Israel with no space to maneuver. The Israeli government was forced to decide whether to accept Kennedy's demands and risk eliminating the Dimona Project or refrain from accepting and risk a confrontation or even a serious rift with the American administration.

On Sunday, June 16, Kennedy sent Ben Gurion another letter. The wording of this letter indicated that he had lost patience in light of what probably seemed to him as Ben Gurion's attempts to waste time without accepting his demands. At the close of his letter, Kennedy outlined a plan for inspections of the reactor. It was unusual for messages between heads of state to include such detail. The nature of the letter indicated how obsessive Kennedy was regarding the Dimona Project. To a large extent this explained his decision to ignore any formal limitations in reaching the goal he had set-a complete freeze of the Dimona Project.

Israel viewed Kennedy's demands as a blow to her sovereignty; some even voiced the complaint that the United States used different criteria than it had in dealing with nuclear activity in other countries, specifically India. Ben Gurion resigned the following day and the letter reached his successor, Levi Eshkol. (It should be noted that there is no indication of a connection between Kennedy's policy and Ben Gurion's resignation). On August 19, 1963, Eshkol replied, including the following points: (1) Israel had gone a long way to satisfy the U.S. demands, which are exceptional given the Dimona reactor was built with no American aid; (2) Israel accepted the demand that the next visit to Dimona would take place before the operating stage of the reactor and not afterwards; (3) Israel accepted Kennedy's suggestion for further visits, starting in June 1964; (4) Israel proposed a way in which U.S. representatives could examine the procedure that is central to fuel fabrication during the visit; and (5) Israel opposed the administration's intention to pass on the findings of the visit to President Nasser of Egypt. Nonetheless, Eshkol noted that this final point could be reconsidered.

In his reply on August 19, Kennedy's tone was softer, which was surprising considering that, on the surface, there were no signs of a significant change 
in the Israeli government's position regarding Dimona. We can assume that the return to a low-key policy regarding Israel's nuclear ambitions was caused by several factors. First, the Kennedy administration may have assumed that at this stage it would be better to tone down the pressure on Israel so as to prevent escalating criticism of Eshkol from his domestic opponents, led by Ben Gurion. Second, information received from intelligence agencies in the United States indicated that Israel's nuclear activity in Dimona had decreased in the given period. Third, President Nasser's refusal to accept the U.S. demands for inspection of Egypt's unconventional weapons activity. This made it more difficult for the administration to pressure Israel to accept similar demands. Based on this, Kennedy said that the Arab countries should be made aware that allowing inspection of their unconventional weapons facilities was in their own best interest, as it would enable the administration to exert similar pressure on Israel.

An additional consideration guided President Kennedy: at that time, the signing of the Comprehensive Test Ban Treaty was on the international agenda. The Kennedy administration believed that the treaty could serve as a powerful stimulus to force different countries with nuclear reactors-including Israel-to agree to closer inspection of their facilities. Israel deliberated at great length about signing this treaty. On one hand, there was fear that refusing to sign the treaty would greatly strengthen the suspicions regarding her nuclear activity, isolate her internationally, and taint her relations with the United States. On the other hand, there was fear that signing the treaty would lead to increased demands for closer inspection of Israel's nuclear activity, thus limiting her sovereignty and her freedom of action in everything related to developing a nuclear option (Shalom 2005, 64).

Another consideration was probably unwillingness to exert greater pressure on Israel in the absence of the administration's preparedness to accept her demand of a bilateral security agreement that would guarantee Israel effective American protection if Israel is attacked. It seems that the Israeli government was aware of the administration's growing unease at not responding to Israel's demands for security guarantees and at the same time discussing inspections of Dimona.

Zaki Shalom reports on a conversation, in mid-September 1963, between Walworth Barbour, U.S. Ambassador to Israel, and Foreign Minister and Deputy Prime Minister Abba Eban. Eban emphasized the importance of a security linkage with the United States. He made it clear that such contact would also serve the vital interests of the United States, mainly the administration's aspiration to prevent a military confrontation in the Middle East. "Eban noted that no state that had a formal defense treaty with the United States had ever been attacked" (Shalom 2005, 65-66). Though he did not say so explicitly, Eban's message was clearly that "if the administration was unable to answer Israel's basic security demands, it would lose any moral justification for pressurizing Israel to halt 
development on its independent deterrent force" (ibid.).

The United States could not ignore the possibility of an Arab-Israel confrontation, which would represent a dilemma for the administration: aid Israel and subsequently risk a severe confrontation with the Arab world and maybe even the Soviet Union, or avoid pro-Israel involvement and risk severe harm to, or even extermination, of the Jewish people. Assumedly, there were administration officials who believed that Israel's nuclear deterrence would also serve American interests in avoiding the dilemma entirely.

It is reasonable to assume that the Kennedy administration knew of the firm stance of Foreign Minister Meir on the policy Israel should use towards the American government regarding Dimona. According to Zaki Shalom, Meir believed that Israel:

needed to "show its cards" to the Americans in everything concerning its nuclear activity. She considered it likely that the Americans would ultimately accept the security explanations that justified Israel's persistence in her nuclear program: "There is no need to cease our activity in Dimona, but we have led ourselves into a situation in which we are unable to derive any benefit from the matter. The present dispute with [the Americans] is whether to tell them the truth or not. I had doubts regarding this from the very beginning of the American involvement. I was always of the opinion that one ought to tell them the truth and to explain to them why, and it doesn't interest us whether or not the Americans agree with us that Nasser is a danger" (Shalom 1996, 23-24).

It is reasonable to assume that this was the general idea that later shaped the Nixon-Golda understandings.

On November 22, 1963, President Kennedy was assassinated and Lyndon Johnson assumed office. Kennedy's relationship with his Vice President was not close and, according to various sources, he avoided sharing information on sensitive national issues with Johnson. Thus, for the time being, the issue of Israel's nuclear activity was pushed aside, though it was not completely removed from the America agenda, and Eshkol was granted a vital break from the question of Dimona.

In the beginning of 1964, the American-Israeli dialogue regarding the Dimona Project was renewed. Up for discussion was coordinating visits to the reactor and transferring information gathered to Egypt. On January 18, 1964, a U.S. inspection team visited Dimona for eleven hours and examined all significant facilities. The team determined that that there were no facilities for plutonium separation. They also determined that at that stage the reactor had no weapons making capability.

On February 20, 1964, Johnson sent Eshkol a letter regarding the Dimona Project. The letter was written in a moderate, placatory spirit-very different from Kennedy's letters of May-June 1963. At the end of the letter, Johnson referred 
to the Dimona Project as one of the issues to be discussed during the Prime Minister's visit to the United States, in order "to avoid unnecessary increases in Arab antagonism, with the consequent weakening of the forces of moderation."

During his meetings with Eshkol in June 1964, Johnson indeed raised, as expected, the issue of inspection of the Dimona facility. Johnson's approach was clear and explicit, though lacking the decisiveness and threatening tone of Kennedy in mid-1963. It can be estimated with a great measure of certainty that Johnson's restrained attitude toward Dimona derived from, among other things, internal political considerations: in November 1964, Johnson would be running for reelection and Eshkol's support, he hoped, would gain him the Jewish vote.

Johnson reminded Eshkol that the United States strongly objected to nuclear weapons proliferation. If Israel, asked Johnson, had no intention of producing nuclear weapons as it maintained, why not agree on international inspection of the Dimona Project and enable the administration to calm Nasser in this respect.

Eshkol replied that Israel could not agree to the United States transmitting project data to Nasser. Nasser, said Eshkol, was Israel's enemy and was not prepared for a peace settlement. Israel, continued Eshkol, believed that action must be taken to replace armistice agreements with peace treaties, instead of going on with the arms race. As long as this did not happen, it was not advisable to pass calming messages of Israel's nuclear activity on to him.

Several days after the meetings with Johnson, probably due to the relaxed atmosphere that prevailed and Johnson's moderate approach to the Dimona Project, Shimon Peres, the Deputy Defense Minister, informed Secretary of State Phillip Talbot of a change in Israel's policy regarding reassuring Nasser about the Dimona Project. Peres told Talbot that, in response to Johnson's request, Israel would consent to the American request to placate Nasser regarding Dimona but without mentioning past visits to Dimona by American scientists.

Several months after Eshkol's meeting with Johnson, the administration renewed pressure on Israel regarding inspection of Dimona. Under these circumstances, Eshkol probably understood that he would not be able to withstand the pressure on him by means that had been effective in the past. Now, he thought, a daring step was needed, one that entailed risks. At the end of October 1964, he sent Johnson a very personal and informal request to postpone the next visit of inspectors to the Dimona reactor until after the Knesset elections that were scheduled for November 1965.

It appears from this report that apparently Eshkol obligated himself to the administration agreeing to a "periodical inspection" of the Dimona reactor. We do not have formal proof of this agreement; maybe it was given orally via informal channels. If indeed such an agreement was given, that was an outstanding deviation from the understandings with the American Administration achieved during Ben Gurion's period, when "a visit" and not "inspection" was being discussed, and that the visit would take place just once a year (Shalom 2004, 173). 
Eshkol no doubt picked the right time to send Johnson a message. The U.S. presidential elections were in the offing. Johnson had to take into consideration the possibility that an unwillingness to respond to such an exceptional request from Eshkol would trickle down to the media and harm his chances of gaining Jewish support. According to Shalom, "McGeorge Bundy clarified that such a sensitive decision, namely whether to respond to Eshkol's request, could not be obtained before the presidential elections. After the elections, he suggested, the implications of postponing the visit to the reactor would be reevaluated. Meanwhile, he recommends, any discussion with Israel on this issue must be suspended" (ibid.).

Eventually the visit took place on January 30, 1965 and lasted ten hours. Although a comprehensive and intensive visit was not possible, the inspection team concluded that they had enough time to determine the nature of activities there. In their report, the inspection team asserted that the reactor had no immediate weapons making capability. However, they clarified that the development and the production capabilities were of a very high standard and recommended continuing periodic inspections not less than once a year. The team also determined that the administration could agree to respond to Eshkol's request to postpone the next semiannual visit at the reactor until after the Knesset elections in November 1965.

Johnson's special envoys came to Israel at the end of February 1965, including veteran diplomat Averell Harriman. They were authorized to discuss an array of subjects relating to the Arab-Israel conflict with the leaders of Israel. On the practical level, their goal was twofold: fist, to obtain a commitment from Israel not to conduct a pre-emptive attack against diversion of the Jordan River waters by Arab countries, but rather seek to solve the problem peacefully, mainly by means of the United Nations (UN); and second, receive Israel's commitment not to develop nuclear weapons and anchoring it by accepting international safeguards on all its nuclear factors.

On February 17, 1965, during the envoys' meeting with the Prime Minister, Eshkol clarified unequivocally to the envoys that the only point he was willing to accept was reemphasizing Israel's commitment not to be the first to introduce nuclear weapons into the area. This wording, he reiterated, was the best he could do. There was no possibility, politically speaking, that the government would accept international inspection of the Dimona reactor when the other powers in the area, especially Egypt, had not taken upon themselves a similar commitment.

The envoys reported that Israel's consent to reaching an agreement with the administration regarding several issues, including the Dimona Project, depended on the administration's willingness to clarify its consent to supply Israel with the weapons she requested. Following this report, the administration was willing to moderate its stance toward Israel and indicated that the United States recognized Israel's need for weapons, especially tanks. Johnson's envoys soon realized that 
the effort to reach a comprehensive agreement that would include full inspection of the Dimona reactor was unrealizable based on stubborn opposition to these demands by Eshkol and his government. Under these circumstances, the administration faced a tough choice: to end the talks with no agreement or go for a limited, naturally vague consent. The issue was brought to Johnson who chose the second alternative-a limited agreement.

A set of understandings between Israel and the United States, dealing with Israel's nuclear activity, was eventually agreed upon on March 10, 1965. The United States and Israel obligated themselves as part of this memorandum of understanding (MoU) to keep its content and the activities completely secret until both governments decided otherwise. The first clause of the MoU stated that the "Government of the United States has reaffirmed its concern for the maintenance of Israel's security and has renewed its assurance that the United States firmly opposes aggression in the Near East and remains committed to the independence and integrity of Israel." The third clause of the MoU referred, somewhat vaguely, to Israel's hope to receive weapons from the United States, stating only that the United States will be ready to "discuss with Israel its needs and problems." The United States recognized "the importance of an effective Israel deterrent capacity," but was not itself obligated to act in order to implement it. In reference to the sensitive issue on the agenda-Israel's nuclear activity-the MoU states only that the "Government of Israel has reaffirmed that Israel will not be the first to introduce nuclear weapons into the Arab-Israel area." The wording of this clause was very convenient for Israel; as long as the American administration was willing not to nitpick the meaning of the term "introducing nuclear weapons" it was clear that the restrictions, referred to by the wording, on Israel's nuclear activities would be minimal. ${ }^{5}$

On January 20, 1969, Richard Nixon was inaugurated. A month later, on February 26, Eshkol passed away, and after a few weeks Meir was sworn in as prime minister. These changes brought to an end the understandings that had been reached in the early sixties between Kennedy and Ben Gurion and continued-with certain modifications-between Johnson and Eshkol.

The new understandings were intended to reflect Nixon and Meir's respective political thought as well as the new political and strategic reality. The new situation is described by Avner Cohen in the following manner:

Under the new understanding Israel was assumed, but not recognized or acknowledged, to be a nuclear weapon state. Nixon and Henry Kissinger, if not the entire State Department, accepted the reality that Israel was in possession of nuclear weapons, and Nixon conveyed to Meir that the United States would not challenge this reality or try to roll it back if Israel kept its nuclear profile low...The most important result of the new understanding was the end of the American visits to Dimona. One more visit was carried out in 1969, and in 1970 the United States gave them up (Cohen 1998, 323). 
The Nixon-Meir meeting in September 1969 was the time to formulate the necessary changes. Nixon and Kissinger were prepared to come to terms with exceptions regarding non-proliferation; they believed that a case in which the U.S. national interest allowed a friendly country to accumulate a reservoir of nuclear weapons of its own was possible. Moreover, Meir had never been in agreement with Ben Gurion or Eshkol, and therefore was not bound to uphold the understandings reached between her predecessors and Kennedy and Johnson. Now she had the opportunity to present her position to the U.S. leaders. According to Cohen (ibid., 336), "in her memoirs Meir does not discuss the substance of her conversation with Nixon, saying only that 'I could not quote him then and I will not quote him now."

Meir adhered to her old views: "Tell the Americans the truth and explain why." Nixon and Kissinger understood why. According to an Israeli source, the wording of the understandings was formalized at a meeting with Kissinger, Ambassador Rabin, and Meir's assistant Simcha Dinitz. According to the same source, when Jimmy Carter entered the White House in early 1977, he was not aware of the secret agreements between Nixon and Meir and was totally obligated to universal non-proliferation. Israeli officials were therefore anxious about the fate of those understandings. Dinitz approached Kissinger and asked him to present the nuclear understandings between the United States and Israel to the new president, as a result of which the understandings were upheld. They have continued to survive through all leadership changes in Washington and Jerusalem from then until the present day.

\section{The U.S. Policy regarding Nuclear Non-Proliferation and its Relation to Israel}

For years, the United States has led international efforts to prevent the proliferation of nuclear weapons. Since the mid-twentieth century, these efforts included a long list of international systems like treaties, organizations, systems of inspection, and legislation.

The NPT is at the center of these efforts. Under the terms of the treaty, the five declared nuclear super powers-the United States, the Soviet Union, Great Britain, France, and China-are to refrain from giving any aid to non-nuclear countries in obtaining nuclear weapons. The five superpowers also agreed to reduce and eventually eliminate their nuclear weapon reserves. The non-nuclear countries agreed not to develop nuclear weapons and to allow the International Atomic Energy Agency (IAEA) to inspect their nuclear facilities, so as to ensure their peaceful use. The treaty promises non-nuclear countries technological access for peaceful purposes.

The treaty was presented for signing on July 1, 1968 when the United States, 
the Soviet Union, Great Britain, and fifty-nine other countries signed it. It became operative on March 5, 1970, when the United States ratified it. China and France joined in 1992. Since the end of the Cold War, the treaty has been signed by almost all countries. Only India, Pakistan, and Israel never signed. North Korea backed out of the treaty in 2003.

In addition to the NPT, the United States offers positive and negative incentives to convince countries interested in nuclear weapons not to produce them. As for countries facing unique security problems, the United States offers them support in the form of alliances that are intended to reduce their interest in nuclear weapons. For example, both Japan and Germany had plans to develop nuclear weapons during World War II, and they may well have continued their plans after the war were it not for the nuclear umbrella that the United States supplied. After the end of the Cold War, Ukraine, Belarus, and Kazakhstan gave up their nuclear capabilities in return for improved relations with the United States.

Imposing sanctions is another way the United States deters and punishes nuclear weapon dissemination. The U.S. Congress has passed many laws that impose sanctions on such countries or others that aid them. The Arms Export Control Act and the Foreign Assistance Act include clauses that call for American aid cutbacks to countries that illegally acquire nuclear weapons or the means to build them (Rennak 2010). Based on these laws, sanctions were imposed on India and Pakistan in 1998 following their involvement with nuclear experimentation.

It is noteworthy that the treaty was designed by two Democratic administrations, believing that nuclear weapon dissemination to other countries would endanger American and global security. Nixon's views of nuclear weapon dissemination were completely different. Favoring political realism, the Republicans tend to be suspicious of international plans and organizations; therefore, the new Republican administration was not overly enthusiastic about the efficiency or benefit of the treaty. At the time, Israel commented on the treaty as if it were still "being studied," but it was clear that Israel had no intention of signing it and hoped that new understandings with the Nixon administration would remove the issue from the agenda. And indeed, that is what happened.

\section{The Nuclear Relations of Israel and the United States: Mutual Advantages}

A "power relationship" must involve at least two sides. But how do the different players evaluate a country's power? Relevant to Israel's nuclear policy, power is determined by the beholder. Any connection between objective power data and power, according to this outlook, is coincidental because power may be virtual. Israel does not lose its nuclear deterrence even when its policy is one 
of ambiguity; as long as Israel creates the image of a player with the possibility of having nuclear weapons, her power exists. In other words, power belongs to whomever you think has it. It is assumption that determines Israel's enemies' attitude toward her, no less than the reality.

Israeli deterrence would not decrease should Israel decide to "take the bomb out of the basement," but in such a case, Israel and its nuclear facilities would be exposed to the international community for inspection, as well as to American sanctions, like those imposed on India and Pakistan in 1998. In addition, Israel would not be able to prevent general nuclear armament in the Middle East and would lose her moral right to demand it. It seems that for all these reasons, Israel's nuclear policy has been a success story.

The question raised here is what motivates the United States to enable Israel to hold such a policy? One answer to this question could be based on cultural relationships. As Samuel P. Huntington expresses it in his "The Clash of Civilizations?": "A world of clashing civilizations, however, is inevitably a world of double standards: people apply one standard to their kin-countries and a different standard to others" (Huntington 1993). He adds, "Conflicts and violence will also occur between states and groups within the same civilization. Such conflicts, however, are likely to be less intense and less likely to expand than conflicts between civilizations. Common membership in a civilization reduces the probability of violence in situations where it might otherwise occur" (ibid.). According to this, it could be argued that the fact that Israel and the United States belong to the same Judeo-Christian civilization has saved Israel from a fate similar to that of India and Pakistan, which belong to different civilizations. Nevertheless, since Israel was the first case of nuclear weapon dissemination and a small, friendly country situated outside the U.S. containment policy zone, the United States decided not to employ pressure.

During the Cold War period, a binding declaration from the administration regarding security guarantees to Israel, including all embracing approval of arms sales, as Israel demanded, could have resulted in the Arabs, mainly Egypt, strengthening relations with the Soviet Union, which could thereby deepen its involvement in Arab countries. The fact that the United States did not pressure Israel on the nuclear project also meant avoiding such a result. On the other hand, one could argue that Israeli nuclear activity itself could enhance the Soviet Union's involvement in the area and perhaps even severely raise inter-superpower tensions. It is hard to determine what the U.S. interest in promoting such a scenario was.

It seems that by adopting a "blind eye policy" toward Israel's opaque nuclear policy-even at the cost of not insisting on the spirit of the NPT-the United States can restate its undisputed commitment to Israel's security; a commitment realized by very generous civil and military aid, in addition to comprehensive political and diplomatic support. All this, without being bound to a formal, 
written agreement. In this way, the United States does not endanger its interests in the Arab world. The best of both worlds for both Israel and America.

Despite the fact that the understandings that underlay U.S. policy toward the Israeli nuclear project were formulated under a Republican administration holding a world view of political realism, Democratic administrations that support multinational diplomacy and arms control have not cancelled them.

It is commonly agreed that the first clause in what could be termed the "Obama Doctrine" was the recognition that the United States must take the lead in a comprehensive international effort to destroy nuclear weapons (Obama 2009). Despite that, Obama, who had promised in every possible forum to safeguard Israel's security, did not have any intention of changing these understandings or of closing down Dimona. Surely not when Iran threatens to wipe Israel off the map and Obama himself was in search of a dialogue with the Muslim world.

On the other hand, should the international community fail in its efforts to prevent Iran from attaining nuclear weapons, Israel might decide to take her bomb "out of the basement" and to establish an open balance of power policy visà-vis Iran. There is reason to assume that such an Israeli step in the future-which would certainly be coordinated with the United States-would be approved by the international community. Such a move would also put an end to the Nixon-Meir understandings. In such a case, there might even be room to consider AmericanIsraeli agreements for the trade of nuclear technology for non-military purposes, like the agreement between the United States and India signed in 2008.

\section{Notes}

1. For a comprehensive historical review of this issue, see Hersh (1991); Cohen (1998); and Shalom (2005).

2. See: Foreign Relations of the United States, 1961-1963, Volume XVIII, Near East, 19621963. Ed. Nina J. Noring (Washington: Government Printing Office, 1995), Document 199.

3. See: Government of the United States of America, Department of State, Presidential Correspondence: Lot 66 D 294.

4. See: National Archives and Records Administration, RG 59, Central Files 1964-66.

5. See: National Archives and Records Administration, RG 59, Central Files 1964-66, DEF 12-5 JORDAN.

\section{References}

Cohen, Avner. 1998. Israel and the Bomb. New York: Columbia University Press.

Cohen, Avner. 2009. "Between Natanz and Dimona." Ha'aretz, May 15. https://www. haaretz.com/1.5053029 (accessed October 13, 2018). 
Hersh, Seymour M. 1991. The Samson Option: Israel's Nuclear Arsenal and American Foreign Policy. New York: Random House.

Huntington, Samuel P. 1993. “The Clash of Civilizations?” Foreign Affairs, June 1. https:// www.foreignaffairs.com/articles/united-states/1993-06-01/clash-civilizations (accessed October 13, 2018).

Obama, Barrack. 2009. "Prague Speech on Nuclear Weapons." April 5. http://www. huffingtonpost.com/2009/04/05/obama-prague-speech-on-nu_n_183219.html (accessed October 13, 2018).

Rennack, Dianne E. 2010. "Nuclear, Biological, Chemical and Missile Proliferation Sanctions: Selected Current Law" CRS Report RL31502, November 30. https://fas. org/sgp/crs/nuke/RL31502.pdf (accessed October 13, 2018).

Shalom, Zaki. 1996. "Kennedy, Ben-Gurion and the Dimona Project, 1962-1963." Israel Studies 1 (1): 3-33.

Shalom, Zaki. 2004. Between Dimona and Washington - The Struggle over Developing the Israeli Nuclear Option 1960-1968. [In Hebrew.] Ben Gurion University: Sde Boker.

Shalom, Zaki. 2005. Israel's Nuclear Option: Behind the Scenes Diplomacy between Dimona and Washington. Brighton: Sussex Academic Press.

Arie Geronik teaches International Relations at the Open University of Israel. He received his Ph.D. from the Hebrew University in Jerusalem in 2002. His fields of research include the foreign policy of Israel, the foreign policy of the United States in the post-war era, and psycho politics. 